A N N A L E S

UNIVERSITATIS MARIAE CURIE-SKŁODOWSKA

LUBLIN - POLONIA

VOL. LXV, 1

SECTIO G

2018

Maria Curie-Skłodowska University, Lublin

ewa.kruk@umcs.pl

EWA KRUK

\title{
The Simplification of Accelerated Proceedings \\ in a Petty Offence Case (Art. 89 et seq. of the Code of Proceedings in Petty Offences Cases). Selected Problems
}

Uproszczenia postępowania przyspieszonego w sprawie o wykroczenie (art. 89 i n. k.p.w.). Zagadnienia wybrane

In all proceedings two opposing tendencies can be observed: to formalise the requirements and to simplify them. The accelerated mode is a typical manifestation of the simplification of court proceedings. This mode is present in two separate statutes, i.e. the Code of Criminal Proceedings ${ }^{1}$ from June 6, 1997 and the Code of Proceedings in Petty Offences Cases from August 24, 2001. ${ }^{2}$ As is justly indicated by Stanisław Waltoś and Piotr Hofmański, the lawmaker generally constructs special proceedings because the typical (ordinary) proceedings are for some reason unsuitable as a result of the presence of specific elements in a given category of cases. ${ }^{3}$ The specificity of different elements of the object of a given case makes it possible to modify the course of proceedings in such a way as to improve procedure taking into account the legal status which is characterised by insignificant degree of social harmfulness, the person of the perpetrator, the character of the forbidden act (a petty offence or a misdemeanor). As a result of the different legal conditions of a given case, the decision about the object of proceedings (no matter if it refers to a petty offence or a misdemeanor) is simplified and is taken in a way significantly different from the rules of decision taking accepted in ordinary proceedings.

\footnotetext{
1 Journal of Laws of 2016, item 1749 as amended.

Journal of Laws of 2001, No. 106, item 1149 as amended.

3 S. Waltoś, P. Hofmański, Proces karny. Zarys systemu, wyd. 13, Warszawa 2016, p. 670.
} 
The object of accelerated proceedings is the decision referring to the responsibility of the person blamed in petty offences proceedings or - in criminal proceedings - of the accused of a forbidden act constituting an offence. In both the criminal and petty offences procedures, the accelerated proceedings are characterised by reduction of formalism replacing the legal restrictions, which explains the specific uniqueness of this type of proceedings and their place in the code systematics in the group of court proceedings belonging to the category of special proceedings (Part X of the Code of Criminal Proceedings and Part IX of the Code of Proceedings in Petty Offences Cases).

It is stressed in literature that accelerated proceedings had appeared on the ground of the formal law on petty offences before it also happened in the formal criminal law on offences, ${ }^{4}$ since its origins go back to 1928. In the binding proceedings in petty offences cases, accelerated proceedings, alongside the ordinary proceedings and penal order proceedings, belong to those proceedings in which decision taking is present, which is the domain of the court. This can be inferred from the disposition of Art. $2 \S 1$ of the Code of Proceedings in Petty Offences Cases, which determines the court character of these proceedings. On the other hand, as can be inferred from Art. $2 \S 2$ of the Code of Proceedings in Petty Offences Cases, this type of proceedings - alongside the penal order proceedings - is preferred by the lawmaker because of its quickness and reduced formalisation. Adjudication in the ordinary mode takes place only when there are no grounds for adjudication in the accelerated mode or penalty order mode. It is emphasised in literature that the sequence of modes established in this provision does not decide about the precedence in their application, ${ }^{5}$ yet one should remember the earlier remark about the subsidiary character of ordinary proceedings, which is the consequence of a situation in which there are no bases for case adjudication in the two other modes. ${ }^{6}$ Such a solution seems to be the right one if one considers the fact that the lawmaker's intention was an efficient and "cheap" reaction of prosecution and justice bodies.

Adjudication of a case in the accelerated mode depends on the presence of special conditions alongside the lack of proceedings obstacles (circumstances excluding adjudication) which are indicated in the provision of Art. 5 of the Code of Proceedings in Petty Offences Cases. ${ }^{7}$ Among the conditions of accelerated

4 W. Cieślak, Postępowanie przyspieszone, [in:] F. Prusak (red.), System prawa karnego procesowego. Tryby szczególne, t. XIV, Warszawa 2014, p. 201 and the literature quoted there.

5 W. Kotowski, B. Kurzępa, Kodeks postępowania w sprawach o wykroczenia. Komentarz, wyd. 3, Warszawa 2016, art. $2 \mathrm{Nb}$ 1, p. 32.

6 Ibidem, p. 32.

7 K. Dąbkiewicz, Komentarz do art. 90 Kodeksu postępowania w sprawach o wykroczenia, legal status for 2014.09.01, LEX 2017. 
proceedings, subjective and objective ones can be distinguished. ${ }^{8}$ As far as the offender is concerned, accelerated proceedings can be conducted in relation to:

1) persons who do not have a permanent place of abode or a place of permanent residence (Art. $90 \S 1$ of the Code of Proceedings in Petty Offences Cases);

2) persons who stay on the territory of Poland only temporarily (Art. $90 \S 12$ of the Code of Proceedings in Petty Offences Cases). ${ }^{9}$

It should be noticed that the term "place of abode" is not separately defined by the Code of Proceedings in Petty Offences Cases, since the term has functioned for many years in civil and administrative law. The legal definition of this term can be found in Art. 25 of the Civil Code, according to which: "The place of abode of a natural person is the locality where the person stays with the intention of permanent residence". In administrative law instead, the term "place of permanent residence" is connected with the registration of a given person and with the place in which the person is conducting his/her basic life functions. ${ }^{10}$ According to the commentators of the civil law, the fact that somebody is registered for permanent residence is not enough to assume permanent abode in the meaning of Art. 25 of the Civil Code. Yet, this may be one of the conditions which make it possible to come to the right conclusion and so make the establishment of facts easier. ${ }^{11}$ As is stressed by Jerzy Strzebińczyk, three elements were used to construct the civil law definition of place of abode of a natural person in Art. 25 of the Civil Code. ${ }^{12}$ The lawmaker used for this purpose the terms "location", "staying [there]" and "intention of permanent residence [there]" ${ }^{13}$ On the grounds of the civil law, the place of abode is connected with the whole territory of a given location and this makes the civil law approach to place of abode different from the common understanding of that term which treats it as a synonym of the registered address (for permanent or temporary residence) of a natural person. ${ }^{14}$ According to that

$8 \quad$ Ibidem and the literature quoted there.

9 Ibidem.

10 On the grounds of administrative law, this term is employed by Art. 6 section 1 of the statute from April 10, 1974 on the record of population and identity cards, Journal of Laws of 2006, No. 139, position 993 as amended. More on this, see: K. Dąbkiewicz, op. cit., and the decisions of the Regional Administration Courts and Supreme Administration Courts quoted there.

11 S. Dmowski, [in:] S. Dmowski, S. Rudnicki Komentarz do Kodeksu cywilnego. Księga pierwsza. Część ogólna, wyd. 10, Warszawa 2011, p. 136. In the civil law literature, a de lege ferenda proposition to change the definition from Art. 25 of the Civil Code so as to approximate it with the common meaning of place of abode was presented by J. Strzebińczyk, [in:] E. Gniewek, P. Machnikowski (red.), Kodeks cywilny. Komentarz, wyd. 7, Warszawa 2016, p. 70 and quoted there - B. Gliniecki, Miejsce zamieszkania, p . 11.

12 J. Strzebińczyk, [in:] E. Gniewek, P. Machnikowski (red.), Kodeks cywilny. Komentarz, wyd. 7, Warszawa 2016, p. 67.

13 Ibidem, p. 67.

14 Ibidem, p. 67. 
author, the interpretation differences in the case of the term "place of abode" stem from the difference of purposes which are to be achieved through the use of the category of place of abode in civil law and the administrative law obligation of address registration which mainly serves the needs of population registration. ${ }^{15}$ The lack of any of the constitutive elements of the definition of place of abode - in Strzebińczyk's opinion - proves that the case concerns persons who purposefully change their places of residence without the intention of staying in any of them for a longer time. Such individuals do not have a place of abode in the meaning of Art. 25 of the Civil Code. ${ }^{16}$

The term "place of abode" in the civil law meaning is accepted by Krzysztof Dąbkiewicz. According to this commentator, the range meaning of the normative terms "permanent place of abode" and "place of permanent residence", which are mentioned in Art. $90 \S 1$ of the Code of Proceedings in Petty Offences Cases in fact intersect and overlap. ${ }^{17}$ In that case - according to that author - the most proper solution is to interpret both terms in the light of Art. 25 of the Civil Code. ${ }^{18}$ This opinion deserves to be approved. A person who does not have a place of permanent abode or a place of permanent residence is a person who in fact has no location of permanent residence. ${ }^{19}$ Yet, the application of the accelerated mode in such a case requires the fulfillment of an additional condition in the form of the presence of "a justified fear that the examination of the case in ordinary proceedings will be impossible or cause great difficulties". ${ }^{20}$ As is rightly stated by Tomasz Grzegorczyk, the decision about the presence of this fear and its degree (justified or unjustified) is first taken by the prosecuting body detaining a given perpetrator and filing a motion to have the case examined in accelerated proceedings, and then the decision is taken by the court president who accepts the motion and does not turn it back or does not direct the case to be tried in the ordinary mode. Also the court has the right referring to this issue as it may change the mode into the ordinary one stating that there are no bases to examine the case in accelerated proceedings (see Art. $92 \S 3$ of the Code of Proceedings in Petty Offences Cases). ${ }^{21}$ As a result, the conducted procedural control makes the conditions justifying the petty offence perpetrator's responsibility in the accelerated mode more rational.

15 Ibidem, p. 67.

16 Ibidem, p. 69.

17 K. Dąbkiewicz, op. cit.

18 Ibidem.

19 J. Lewiński, Komentarz do Kodeksu postepowania w sprawach o wykroczenia, Warszawa 2009, p. 262.

20 Ibidem.

21 T. Grzegorczyk, Postępowania szczególne w sprawach o wykroczenia, „Prokuratura i Prawo" 2002, nr 1, p. 41; see also: W. Kotowski, B. Kurzępa, Kodeks postepowania w sprawach o wykroczenia. Komentarz, wyd. 3, Warszawa 2016, p. 387. 
Accelerated proceedings may also be applied to persons staying only temporarily on the territory of the Republic of Poland. It is assumed in literature that both a foreigner and a person possessing Polish citizenship may be considered to be a person staying only temporarily on the territory of Poland..$^{22}$ It is justly pointed out by Grzegorczyk that in the case of a perpetrator's temporary residence in Poland it is important to determine the character of such a residence. ${ }^{23}$ According to that author, a different approach should be adopted if the perpetrator of a petty offence is just a tourist who may leave the country at any moment and a different one if he/she is temporarily employed in Poland. ${ }^{24}$ In the case of these persons, the application of the accelerated mode requires the fulfillment of yet another condition in the form of a justified fear that the examination of the case in ordinary proceedings will be impossible or cause great difficulties. The presence of the "fear" is caused by such a short staying of the perpetrator that it makes the chance of bringing the case to trial in ordinary proceedings minimal. ${ }^{25}$

The objective range of accelerated mode application should be justified by the character of the committed petty offence. This can be inferred from the text of Art. $90 \S 3$ of the Code of Proceedings in Petty Offences Cases. "Decision taking in the accelerated mode may take place (...) in the case of perpetrators of petty offences committed in connection with a mass event described in the provisions referring to the safety of mass events" ${ }^{\prime 26}: 1$ ) against public peace and order, described in Art. 50. 50a and 52a of the Code of Petty Offences, 2) against property and facilities open to public use, described in Art. 124 and 143 of the Code of Petty Offences. The main condition for applying the accelerated mode ("only when") is the requirement that the perpetrator should be caught in the act of committing the misdeed or directly after the commission of the petty offence and he/she should be delivered to the court without unnecessary delay (see: Art. 91 of the Code of Proceedings in Petty Offences Cases). It is accepted in the doctrine that the term "caught in the act of committing the petty offence" should be understood as referring both to the catching of the perpetrator while he is still fulfilling the statutory features of the petty offence, including an attempt to commit it, when it is punishable or instigation and abetting, as well as catching the perpetrator directly after the commission of the petty offence, i.e. catching him in the place where the petty offence was committed or during a chase undertaken when the perpetrator was

22 J. Lewiński, Komentarz do Kodeksu..., op. cit., p. 262.

23 T. Grzegorczyk, Kodeks postepowania w sprawach o wykroczenia. Komentarz, wyd. 5, Warszawa 2012, p. 313.

24 Ibidem, p. 313.

25 J. Lewiński, Komentarz do Kodeksu..., op. cit., p. 263.

26 Statute from March 20, 2009 on the safety of mass events, Journal of Laws of 2015, position 2139 as amended. 
trying to leave that place. ${ }^{27}$ The chase has to be uninterrupted as the catching of the offender must take place directly after the forbidden act, therefore, a break in the chase eliminates this directness. ${ }^{28}$ The presence of these bases is not decisive for the examination of the case in the accelerated mode. These proceedings are facultative which means that even the presence of the statutory conditions does not mean that the case will be decided in such a mode. As has been already mentioned, during the initial stage the decisive body is the one which caught and detained the perpetrator and, on the basis of verifiable evidence material assumed that the right decision would be to prepare and then direct to the court a motion for punishment. Once the motion has been filed, the control of the justification for that decision is performed by the president of that court which is the right one to examine the case. ${ }^{29}$ The control of the motion for punishment performed by the president of the court makes it possible to issue a decision referring to the existence of justified grounds for conducting proceedings in the accelerated mode and as a result the decree directing the case to trial should be issued without delay or, if the lack of grounds for the examination in accelerated proceedings is stated, the president of the court should direct the case to be examined in ordinary proceedings or return it to the prosecutor in order to have it completed. The court issues the decision to change the mode from accelerated to ordinary when the lack of grounds for conducting proceedings in the accelerated mode has been detected after the initiation of the proceedings (Art. $92 \S 3$ point 2 of the Code of Proceedings in Petty Offences Cases).

The ratio legis of accelerated proceedings in petty offences cases is connected with the fast and effective reaction to law infringements perpetrated by persons in whose case proceedings conducted in the ordinary mode would be difficult or even impossible, and, furthermore, it refers to acts which are socially burdensome. ${ }^{30}$ Such a purpose of these proceedings made it necessary to create such institutional modifications within the process which would guarantee the fulfillment of that purpose.

There are the following simplifications of proceedings in the accelerated mode:

1) restricting the requirements of the motion for punishment to the ones indicated in Art. $57 \S 2$ and 3 point 1 and 3 of the Code of Proceedings in Petty Offences Cases and the right to file the motion orally to be protocolled (Art. $92 \S 1$ point 1 of the Code of Proceedings in Petty Offences Cases);

2) the court should start examining the case without unnecessary delay and there is the requirement to mention in the protocol that the case is conducted in the

27 T. Grzegorczyk, Kodeks..., p. 315.

28 Ibidem, p. 315.

29 W. Kotowski, B. Kurzępa, op. cit., p. 387.

30 Ibidem, p. 387. 
accelerated mode and to note the time of bringing the offender to the court (Art. $92 \S 1$ point 2 of the Code of Proceedings in Petty Offences Cases);

3) imposing on the defendant the obligation to remain at the court's disposal until the trial is terminated on pain of issuing the verdict without his/her presence; a verdict issued in such a way is not considered to be an in absentia one (Art. $92 \S 1$ point 3 of the Code of Proceedings in Petty Offences Cases);

4) the shortening of the duration of a break in the trial (Art. $92 \S 1$ point 4 of the Code of Proceedings in Petty Offences Cases);

5) the preparation of the verdict's written motives only at a party's motion presented orally to the protocol of the trial directly after the verdict has been announced (Art. $92 \S 1$ point 5 of the Code of Proceedings in Petty Offences Cases);

6) the time limit for lodging an appeal, which starts running from the date when the verdict has been delivered with the written motives (Art. $92 \S 1$ point 6 of the Code of Proceedings in Petty Offences Cases);

7) examining the case by the appellate court within a month from the lodging of the appeal (Art. $92 \S 1$ point 7 of the Code of Proceedings in Petty Offences Cases).

The accusatory principle is binding in all court proceedings, including the ones referring to the responsibility for committing a petty offence. According to Art. $14 \S 1$ of the Code of Criminal Proceedings, proceedings are initiated at the request of the prosecutor or another competent body. The motion for punishment prepared and presented by a body competent to assume the role of a public prosecutor constitutes the indictment initiating proceedings before a First Instance Court in ordinary petty offences proceedings (see: Art. $57 \S 1$ of the Code of Proceedings in Petty Offences Cases, the first sentence). The lawmaker accepts a shortened content of the motion for punishment in accelerated proceedings. The structure of such a motion is similar to the "motion for examination" of a case in an offence case. Each of the above mentioned motions, in proceedings referring to a petty offence or an offence, belongs to that category of indictments which initiate proceedings before the First Instance Court in a specified mode. Making an attempt to establish the character of the "motion for punishment" in accelerated proceedings one should use the opinions of the criminal procedure doctrine referring to that issue. Wojciech Cieślak uses the term "surrogates of an act of indictment" to refer to those acts of will of a competent prosecutor which, though they do not have the form of an act of indictment, express the request of that prosecutor to initiate court proceedings and decide about criminal responsibility. ${ }^{31} \mathrm{~A}$ similar opinion is expressed by Kazimierz Zgryzek, according to whom the indictment of a competent prosecutor is a statement of will of a postulating character by which

31 W. Cieślak, op. cit., p. 258. 
the prosecutor demands that the case should be examined by the court since the evidence gathered in the case, in his opinion, makes it possible to initiate court proceedings and - as a result - to issue a verdict confirming the theses presented in that demand..$^{32}$ According to Zgryzek, in the Code of Criminal Proceedings the following documents replace the act of indictment: the motion for the conditional discontinuance of proceedings and the motion for examination, which are called quasi-acts of indictment by that author. ${ }^{33}$ In his opinion, this is justified not only by the terminology used by the lawmaker but also by the meaning (legal character) of the above-mentioned procedural documents. ${ }^{34}$

The indictment, i.e. the demand of a competent body, is the condition of initiating and conducting proceedings and decision taking by the court, ${ }^{35}$ and this refers to almost any court case, no matter in which mode it is to be conducted. "The basis for initiating proceedings is the motion for punishment filed by the competent body entitled to act as a prosecutor in a given case, and in the cases indicated in Art. $27 \S 1$ and 2, including a motion filed by the victim" (Art. 57 $\S 1$ of the Code of Proceedings in Petty Offences Cases). It is assumed that the motion for punishment plays an identical role as the act of indictment in criminal proceedings. ${ }^{36}$ It constitutes an indictment labelled as motion since such a terminology is adopted by the lawmaker in the Code of Proceedings in Petty Offences Cases. In accordance with the accusatory principle, the court may not go beyond the boundaries of the motion for punishment. Such an opinion was also expressed by the Supreme Court in a verdict from May 17, 2011:37

the motion for punishment, as an indictment constituting the basis for initiating proceedings in a petty offence case, should indicate subjective and objective boundaries of these proceedings. The interdiction to trespass the boundaries of indictment means that no examination outside of the framework of the event which is the object of the motion for punishment is possible. The boundaries of the motion for punishment are set, among others, by the description of the act the perpetrator is blamed for, with the indication of the place, time and means of committing it (Art. $57 \S 2$ point 2 of the Code of Proceedings in Petty Offences Cases), and not by the documents accompanying the motion (...).

In the ordinary petty offence court proceedings, the motion for punishment filed by the competent prosecutor constitutes the principle indictment, while in

${ }^{32}$ K. Zgryzek, Skargi zastępujące akt oskarżenia w polskim procesie karnym, [in:] A. GereckaŻołyńska, P. Górecki, H. Paluszkiewicz, P. Wiliński (red.), Skargowy model procesu karnego. Księga ofiarowana Profesorowi Stanistawowi Stachowiakowi, Warszawa 2008, p. 419.

33 Ibidem, p. 418.

${ }^{34}$ Ibidem, p. 418.

35 M. Rogalski, [in:] M. Rogalski (red.), Kodeks posteppowania w sprawach o wykroczenia. Komentarz, Warszawa 2009, p. 70.

36 W. Kotowski, B. Kurzępa, op. cit., p. 299.

37 III KK 96/11, KZS 2011, No. 9, position 37, LEX No. 795787. 
the accelerated proceedings, the motion fulfills the function of a surrogate of the motion described in Art. 57 of the Code of Proceedings in Petty Offences Cases.

Undoubtedly, the opinion of Zgryzek should be shared, according to whom "every indictment initiating proceedings before a court should take on the form of a proceedings written document", which, besides the common features described in Art. 119 point 1-4 of the Code of Criminal Proceedings, should "conform to some special features", which together form the so-called essentialia negotii. ${ }^{38}$ The same specific features constitute, at the same time, an element differentiating it from other proceedings documents, and also from other indictments. Not every indictment has to conform to all identical special features.

In the "ordinary" petty offences proceedings, the indictment initiating proceedings before a court is the motion for punishment which has to conform to the requirements of a proceedings document and, furthermore, contain those formal elements of a motion for punishment which, according to Art. $57 \S 2-3$ of the Code of Proceedings in Petty Offences Cases, are characteristic for an indictment of that type. Art. $57 \S 2$ contains the necessary requirements for every type of motion for punishment, no matter who files the motion ${ }^{39}$, which does not refer to the situation described in $\S 2$ point 4 in fine, according to which the information about the address of the author of the motion is required if it is filed by the victim. More extensive requirements refer to the institutional prosecutor, who should attach to the motion for punishment the materials of the explanatory activities or of preparatory proceedings and also to notify the court of the addresses of witnesses and victims and attach one copy of the motion for each of the defendants $(\S 4){ }^{40}$ Already at this stage, the visibly lower level of formalisation of accelerated proceedings can be perceived since Art. $92 \S 1$ point 1 of the Code of Proceedings in Petty Offences Cases exempts the party filing the motion for punishment from the necessity of placing in it the elements indicated in Art. $57 \S 2$ and $\S 3$ point 1 and 3 of the Code of Proceedings in Petty Offences Cases. ${ }^{41}$ Such a motion for punishment may assume a simplified form, ${ }^{42}$ i.e. be reduced to the indication of the name and surname and address of the defendant (Art. $57 \S 2$ point 1), indication of evidence (Art. $57 \S 2$ point 3), indication of provisions which the alleged act fulfills (Art. $57 \S 3$ point 1), the victims, if any were disclosed (Art. $57 \S 3$ point 3

38 K. Zgryzek, op. cit., p. 419.

39 J. Paśkiewicz, [in:] M. Rogalski (red.), Kodeks postępowania w sprawach o wykroczenia. Komentarz, Warszawa 2009, p. 259.

40 The public prosecutor attaches to the motion for punishment the materials of preparatory proceedings when such proceedings were conducted in an offence case and as a result of legal qualification change it was later assumed that the committed act constituted an offence.

${ }_{41}$ W. Cieślak, op. cit., p. 256.

42 T. Grzegorczyk, Postępowania szczególne w sprawach o wykroczenia, „Prokuratura i Prawo" 2002, nr 1, p. 43. 
of the Code of Proceedings in Petty Offences Cases). The possibility of reducing the content of the motion for punishment indicated in Art. $92 \S 1$ point 1 of the Code of Proceedings in Petty Offences Cases ("it may") means that such a simplification is only allowed but it is not an obligation imposed on the prosecutor to be applied in every case which is to be conducted in accelerated proceedings. The opinion of Maciej Rogalski referring to this should, therefore, be shared ${ }^{43}$. If the discussed simplification is not obligatory, then it is also acceptable to place in the motion all the data that the statute allows to omit or some of them.

In ordinary petty offences proceedings, the only form of the motion for punishment is the written form. In accelerated proceedings the motion for punishment may have both the written form and the oral one noted down in the trial protocol, which is an acceptable alternative (see, however, Art. 92a point 1 of the Code of Proceedings in Petty Offences Cases), but not an obligatory one. The decision is taken by the prosecutor and the court has no right to force him to anything in this respect. The lawmaker, by granting the right to file that motion orally to the trial protocol, introduces an exception from the principle of filing a motion for punishment in a written form, though the principle is not directly expressed but can be inferred from many provisions (e.g. Art. $26 \S 1$, Art. 67 $\S 1){ }^{44}$ The filing of the motion for punishment to the protocol should be done according to the general rules of preparing a protocol describing the activities conducted outside the trial (see Art. $148 \S 1$ point 1 and Art. $150 \S 1$ of the Code of Criminal Proceedings in connection with Art. $37 \S 5$ of the Code of Proceedings in Petty Offences Cases). ${ }^{45}$ Since the motion filed orally to the protocol should conform to the formal requirements identical with the ones for a written motion for punishment, ${ }^{46}$ in practice the wording of such a motion ad hoc (by a policeman or a Frontier Guard officer) may cause some difficulties connected e.g. with the lack of sufficient experience in preparing proceedings documents. Therefore, one should share the opinion of Janusz Lewiński who, referring to this issue, claims that the filing of such a motion orally to the protocol may, contrary to expectations, lead to no simplification and acceleration of the activity of the body presenting that motion, and additionally it engages the court employees for that activity. ${ }^{47}$

In accelerated proceedings, the motion for punishment, no matter what its form is, should conform to all the requirements which refer to the motion filed in a written form. ${ }^{48}$ It undergoes the initial control performed by the president of the

43 M. Rogalski, Komentarz do art. 92 Kodeksu postępowania w sprawach o wykroczenia, LEX 2009, t. 1.

44 J. Lewiński, Komentarz do Kodeksu..., op. cit., p. 270.

45 Ibidem, p. 270.

46 Ibidem, p. 270.

47 Ibidem, p. 270.

48 J. Paśkiewicz, op. cit., p. 341. 
court or a competent judge who is on duty. As is pointed by Cieślak, as far as the formal control of the "motion for examination" is concerned,

the control range includes: verification whether the motion meets the formal requirements specific for it: the specificity of the accelerated mode requires the checking of the time, with the indication of the exact time the motion was delivered to the court, the defendant was placed at the court's disposal (the beginning of the time of case examination by the court) and the date and time of detaining the defendant by the police; these facts need to be established in order to take the possible decision to set the accused (or the defendant - added by E.K.) free or to decide whether examination of the case in accelerated proceedings is admissible (e.g. whether the time for presenting the motion for examining the case in accelerated proceedings has not elapsed). ${ }^{49}$

The described control process of a motion for examination also illustrated the formal control of a motion for punishment. If the motion for punishment conforms to the formal requirements indicated in Art. $57 \S 2$ and 3 point 1 and 3, the president of the court issues a decree directing the case to the trial. Should already at this stage of the proceedings any of the circumstances excluding proceedings be detected (Art. $5 \S 1$ ) - he/she issues a decision refusing to initiate accelerated proceedings. Should it be established that there are no conditions justifying conducting the case in accelerated proceedings, the president of the court, before initiating proceedings, returns the motion to the prosecutor to remove formal shortcomings in the case when the motion was limited to the requirements indicated in $\S 1$ point 1. If the motion for punishment conforms to the requirements of Art. $57 \S 2-4$, it is examined during ordinary proceedings.

A crucial issue for the examination of a petty offence case is the date of initiating proceedings before the First Instance Court, and to be precise: the date of issuing the decree directing the case to trial. In ordinary proceedings, the date of directing a case to trial is important because it is strictly connected with the statutory limitation period for petty offences. As is stressed by commentators, ${ }^{50}$ directing a motion for punishment to the court does not interrupt the limitation period for petty offences. It is only interrupted by the initiating of proceedings resulting from the proper court's decision. The initiation of proceedings in a petty offence case takes place when the president of the court issues a decree ordering the initiation of proceedings ${ }^{51}$ In the accelerated mode things are a bit different because the court is restricted by an additional condition of examining the case "without unnecessary delay". This time limit has been incorporated into the time framework of previously undertaken procedural activities. And so, detention according to Art. $45 \S 1$ of the Code of Proceedings in Petty Offences Cases,

49 W. Cieślak, op. cit., p. 273.

50 W. Kotowski, B. Kurzępa, Kodeks postępowania w sprawach o wykroczenia. Komentarz, wyd. 3, Warszawa 2016, art. 59, Nb. 3, pp. 306-307.

${ }_{51}$ Supreme Court's Verdict of 7 March 2012, K.K. 39/12, OSNK 2012, No. 6, position 67. 
i.e. catching the perpetrator in the act of committing the petty offence, gives to the competent body the right to introduce (or not) the accelerated proceedings under the condition that the deadline from Art. $46 \S 6$ of the Code of Proceedings in Petty offences Cases is respected. According to that provision, "the time of detention is counted from the moment of catching the person and it cannot exceed 24 hours in the cases indicated in Art. $45 \S 1$ point 1 of the Code of Proceedings in Petty Offences Cases, and 48 hours - when there are grounds for applying accelerated proceedings" (Art. $46 \S 6$ ). It means that the detained person has to be set free immediately when the time of detention expires. The application of the accelerated mode means that there is the necessity of shortening the proceedings before the First Instance Court, and this, in turn, is connected with the necessity of modifying this stage in comparison with other modes..$^{52}$ Examining a case without unnecessary delay means examining it as quickly as it is only possible, and in the case of these proceedings the examination should take place within the statutory time limit of the defendant's detention.

The court starts examining a case by calling it (Art. $71 \S 1$ of the Code of Proceedings in Petty Offences Cases). It should be marked in the protocol of the trial that the case is conducted in the accelerated mode, that the defendant was obliged by the court to remain at its disposal until the conclusion of the trial on pain of issuing the verdict without his/her presence which would not be treated then as an in absentia one and also the time of delivering the defendant to the court should be recorded (Art. $92 \S 1$ point 2 and 3 of the Code of Proceedings in Petty Offences Cases). Joanna Paśkiewicz is right when she states that in the case when the circumstances of the case indicate the need to decide about the immediate execution of the convicting sentence, especially when the punishment of arrest and the immediate placing of the convicted person in a penal institution are advisable (see: Art. $82 \S 5$ of the Code of Proceedings in Petty Offences Cases), the court should not just oblige the defendant to stay at its disposal, but it should issue, on the basis of Art. $374 \S 2$ of the Code of Criminal Proceedings in connection with Art. 81 of the Code of Proceedings in Petty Offences Cases, a decree ordering the defendant not to leave the court before the trial is terminated. Issuing such a decree, in that author's opinion, may be also very helpful in the case when the detention of the passport (or another document allowing its owner to cross the border) is decreed in order to execute the punishment (see: Art. $82 \S 5$ point 1 of the Code of Proceedings in Petty Offences Cases)..$^{53}$

The institution of "a break in trial" is applied in all court proceedings. In ordinary proceedings, each break cannot last longer than 21 days (Art. 79, second sentence of the Code of Criminal Proceedings), and the consequence of exceeding

52 W. Cieślak, op. cit., p. 273.

53 J. Paśkiewicz, op. cit., p. 341. 
the time of a break is the court's obligation to issue a decision to postpone the trial. In accelerated proceedings, the break in trial gets radically reduced and it cannot exceed three days. If the trial is broken for a period longer than 3 days, the case has to be examined in ordinary proceedings (Art. $92 \S 1$ point 4 of the Code of Proceedings in Petty Offences Cases). The reduction of the break period is the natural consequence of the fact that the lawmaker wants to make proceedings referring to some petty offences more efficient. The reasons for issuing a decree ordering a break are the same for all types of court proceedings, which is clearly shown by the fact that Art. 89 of the Code of Proceedings in Petty Offences Cases contains the reference to Art. 79 of the Code of Criminal Proceedings. According to that provision, the "court may issue a decree ordering a break in trail to have the defendant delivered, to have evidence delivered, when rest is needed or for another important reason" ( $§ 1$, first sentence). "Issuing a decree ordering a break in trial, the court indicates the time and place of the remaining part of the trial, informs about the obligation to appear in court without summons and about the consequences of not appearing without justification" $(\S 2)$. While in ordinary proceedings, the above-mentioned reasons justifying a break seem to be obvious and understandable, in accelerated proceedings, one of the circumstances justifying a possible break in trial may cause some doubts. This refers to the decree ordering a break for the purpose of delivering the defendant to the trial in the case when the defendant is released pending the trial as a result of an earlier decision to resign from delivering the perpetrator of a petty offence to the court. Such a resignation takes place in two cases: 1) in the situation indicated in Art. 91 § 2a of the Code of Proceedings in Petty Offences Cases, when the body described in its $\S 2^{54}$ ensures that the perpetrator will participate in all court activities in which he/she has the right to participate, and especially the possibility of making a statement with the use of technical facilities which make it possible to conduct that activity at a distance with simultaneous broadcast of images and sounds (Art. $91 \S 2$ of the Code of Proceedings in Petty Offences Cases); 2) in the situation indicated in Art. $91 \S 3$ of the Code of Proceedings in Petty Offences Cases, i.e. when the body described in $\S 2$ imposes on the defendant the obligation to appear in the court at the indicated time and place with the consequences of summons which are described in Art. $71 \S 4$ of the Code of Proceedings in Petty Offences Cases. "A verdict issued without the presence of such a perpetrator is not considered to be an in absentia one". In the light of these provisions, the police or another competent body have

54 Art. $91 \S 2$ of the Code of Proceedings in Petty Offences Cases states that "The police and another body which is entitled the special statutes to perform tasks referring to the protection of public order or safety, in the case of catching a person in the act of committing a petty offence mentioned in Art. 90, may detain that person and deliver him/her to the court (Journal of Laws of 2013, position 395 as amended). 
the right to resign from the above mentioned activities imposing on the petty offence perpetrator at the same the obligation, in the form of a caution, to appear in the court at the indicated time and place. These bodies are obliged to instruct the perpetrator that in the case of an unjustified absence at the trial, the court may issue a decision about detaining him and delivering by force to the court or the court may conduct the trial without his/her presence and the verdict then issued will not be considered an in absentia one. ${ }^{55}$ Art. $91 \S 2$ and 3 of the Code of Proceedings in Petty Offences Case refer to different situations connected with the commission of a petty offence. The statute refers to the possibility of resigning by the prosecution bodies, in the case of some offenders, "from detaining and delivering the offender to the court when there is no justified fear that the offender will not appear in the court and that the court will consider the participation of the offender in the trial necessary". ${ }^{56}$

In the light of the above, the purposefulness of decreeing a break at the early stage of the trial may be questioned. It seems reasonable to assume that if the prediction made by the detaining body about "the lack of justified fear of not appearing in the court" is not confirmed by the fact that the defendant fulfills that obligation, one should assume that the defendant has "grossly abused the trust of the prosecution body". As a result of the situation of "resigning from delivering" the unjustified lack of appearance in the court takes place and at the same time the previously made diagnosis about the defendant is disproved which in the end is correlated with the infringement of the obligation to appear in person before the court. For that reason the decree ordering a break during this early stage of the trial will lead to further consequences, i.e. infringing the time of the examination of the case "without unnecessary delay". Furthermore, it should be observed that issuing the decree ordering a break even for the maximum time span will not guarantee the efficiency of the execution of the decree by the police. It seems that the effort of the public authority body and the financial means spent for this purpose may lead to a breach of proportions between the delivering of the defendant and issuing a quick decision about the case on the one hand, and the financial means spent on it on the other hand. Issuing a decree ordering a break in trial in order to deliver the defendant to the court leads to the slowing down of the trial stage from the very beginning. The decree ordering a break may also be questioned in proceedings in which multiple defendants appear at its calling stage, if there are a few defendants to be held responsible before the court and at least one of them has not appeared in person at the indicated time. In the case in which e.g. one of

55 J. Lewiński, Komentarz do art. 91 Kodeksu postępowania w sprawach o wykroczenia, legal status for: 2011.04.01, http://wpia.lex.umcs.lublin.pl/lex/content,rpe?/reqld=1508757429389_1791 398723\&localNro part=587483819\&nro=201336070 [access: 23.10 .2017 ].

56 Ibidem. 
the co-defendants discloses the intention of not appearing on the other defendant's part, discloses facts making it probable that he/she is hiding or has escaped, the decree ordering a break should be considered groundless. Therefore, it seems that in accelerated proceedings the defendant's unjustified lack of appearance should constitute a reason for changing the mode from the accelerated to the ordinary one. Against the background of not fulfilling a procedural obligation, the decree ordering a break is infringing the priority of that mode referring to the speedy examination of a case.

Another simplification is connected with the issue of preparing the motives of the sentence. Also in this mode it is prepared only on a party's motion ${ }^{57}$ filed in the oral form to the protocol directly after the sentence has been announced (Art. 92 $\S 1$ point 5 of the Code of Proceedings in Petty Offences Cases). The modification introduced by the statute changing the Code of Proceedings in Petty Offences Cases of 27 September 2013 deleted the court's obligation to prepare the written motives ex officio in the situation when the defendant, contrary to the obligation imposed on him by the court to stay present during the trial, has left the trial before it finished or not heeding the obligation imposed on him by the detaining authority, has not appeared in the court though his detention was renounced (Art. $92 \S 1$ point 5 in principio in connection with Art. $92 \S 1$ point 3 and Art. $91 \S 3$ of the Code of Proceedings in Petty Offences Cases). From the point of view of the theory of law, the modification of that provision does not restrict the defendant's right to orally file the motion for the preparation of written motives of the sentence under one condition - that he is present at the trial. Some doubts arise in those cases when the defendant is not present at the trial or when his participation in the trial has been limited by him to a given stage of that trial. Such a situation may take place, for example, in relation to the forms of participation in the trial accepted by the defendant himself. So, the defendant e.g. appears at the trial and then intentionally resigns from the further part of the trial, leaving it contrary to the court's order. Such a behaviour results in the issuing of a verdict which is not considered to be an in absentia one. In this way, however, the defendant deprives himself of the possibility of listening to the sentence and its oral motives. Taking into account the dynamics of proceedings, such a behaviour does not exclude the possibility that he may later have the will to file the motion for the justification of the sentence and, as a consequence, the will to appeal from the sentence of the First Instance Court. The problem is that such a will cannot be effectively executed before the court. Another situation is connected with the unjustified absence of the defendant at the initiating stage of the trial which results in the court's decision to examine the case during the defendant's absence. As a consequence of the already taken decision, the defendant appears at the trial only at the stage of sentence announcement and

57 Though, according to the draft bill, the court was to prepare the written motives ex officio. 
then files the motion to the protocol. The question that arises here is whether in such a case, the defendant has the right to file the motion for the preparation of the written motives of the sentence or whether the previous unjustified absence deprives him of that right. In my opinion, the unjustified absence of the defendant during the initial stages of the trial should not deprive him of the right to file that motion at the proper moment and in the right form. That motion should cause the preparation of the written motives of the sentence by the court.

The last example refers to the proceedings in which there are multiple defendants. The question in such a case is whether all of them or only that defendant who did not appear in court or left the trial out of his own will should be deprived of the right to the motion. In such a case it should be assumed that the absence of one of the defendants makes it impossible for him to perform that activity at the time and in the form provided by the law, under the condition that the defendant does not have a legal advisor. If the defendant is using the help of a legal advisor, that legal advisor will be entitled to file the motion for the motives of the sentence to the trial protocol. The problem of orally filing the motion by the legal advisor of the defendant is identical in multiple defendants proceedings in the absence of at least one of them. If the defendant does not have a legal advisor it will not be admissible to allow a present co-defendant or his legal advisor to file that motion on behalf of the defendant who is absent or has left the trial without the court's permission. This condition for obtaining the written motives of the sentence, as a result of the requirement to file the motion orally after the announcement of the sentence, makes the securing of the procedural rights of the defendant doubtful. It seems that the court's decision to proceed during the defendant's absence deprives the defendant of the right to actually execute the action of filing the motion for the written motives of a sentence in the form and at the time provided by the law and as a result such a decision leads to depriving the defendant of the written motives of the sentence which in turn makes appealing from the sentence of the First Instance Court inadmissible.

By restricting the motion for sentence justification only to the oral form, the lawmaker a priori limited the rights of that defendant who out of his own will, without proper justification, does not participate in the trial. Filing such a motion in a written form causes leaving it without examination since the statute does not provide for such a form of that motion for sentence motives in accelerated proceedings. If the reasonable lawmaker had accepted the written form of that motion as an alternative to the oral one, then it would not have been necessary to point expressis verbis to the form of the motion in Art. $92 \S 1$ point 5 of the Code of Proceedings in Petty Offences Cases.

It should be also emphasised that the lawmaker wants the motion for sentence written motives to be filed "after the announcement of the sentence", so it is to be done before the oral motives of the sentence are presented according to Art. 418 
of the Code of Criminal Proceedings in connection with Art. $82 \S 1$ of the Code of Proceedings in Petty Offences Cases, which seems to be a premature solution and may result in some hastiness of the defendant's decision. It is true that Grzegorczyk does not exclude in such a case the possibility of withdrawing the motion by the defendant who should be instructed about the demand indicated in Art. $92 \S 1$ point 5 of the Code of Proceedings in Petty Offences Cases. It seems, however, that it would be a better solution to move the filing of the discussed motion to the moment after the announcement of the oral motives of the sentence. The instructing should be performed according to Art. 16 of the Code of Criminal Proceedings in connection with Art. 8 of the Code of Proceedings in Petty Offences Cases. ${ }^{58}$

Appeal and complaint are the remedies in the proceedings in petty offences cases (Art. $103 \S 1$ of the Code of Proceedings in Petty Offences Case). The parties have the right to appeal from the First Instance Court's sentence, unless the statute provides otherwise (Art. $103 \S 2$ of the Code of Proceedings in Petty Offences Cases), while they, or the person to whom a decision, decree or another activity directly refer, have the right to a complaint only in cases indicated in the statute (Art. $103 \S 1$ of the Code of Proceedings in Petty Offences Cases). Otherwise than in the ordinary proceedings, in which the time for lodging an appeal is 7 days, in accelerated proceedings the time is significantly shortened and it is only 3 days. Such a shortening is provided for, at the very beginning, by Art. $105 \S 1$ in fine of the Code of Proceedings in Petty Offences Cases "unless it is provided by the statute otherwise"). Such a distinctiveness is characteristic for the time limit indicated by Art. $92 \S 1$ point 6 of the Code of Proceedings in Petty Offences Cases. The time limit for lodging a remedy in accelerated proceedings is 3 days and it starts at the moment when the sentence with its written motives has been delivered to the parties. The examination of the case by the Second Instance Court should take place within a month from the lodging of the appeal (Art. $92 \S 1$ point 7 of the Code of Proceedings in Petty Offences Cases), yet it should be stressed that this time limit is only an instructional one. Having in mind the specificity of these proceedings the failure to comply with this time limit should be especially justified. It seems that the instructive character of the time limit does not effectively motivate the court to examine the case quite quickly.

To sum up, it should be stated that the examining of a case by a court in petty offences cases in accelerated proceedings could favour taking quicker decisions in minor cases, which are also characterised by not very complicated circumstances. The statistics of motions for punishment directed to courts in petty offences

58 T. Grzegorczyk, Komentarz do art. 92 Kodeksu postępowania w sprawach o wykroczenia, LEX 2012, vol. 2. 
proceedings shown below demonstrate a relatively low percentage of motions for punishment in accelerated proceedings.

It can be inferred from the materials gathered by the Statistical Control Information Division of the Department of Strategy and European Funds of the Ministry of Justice that the initiation of proceedings in petty offences cases on the basis of a motion for punishment in accelerated proceedings in the period 2007-2016 and in the first half of 2017 was as follows:

Table 1. The number of initiated proceedings and decisions on persons charged with petty offenses in the years 2007-2016 and in the first half of 2017

\begin{tabular}{|c|c|c|c|c|c|c|}
\hline \multirow{2}{*}{ Year } & \multicolumn{2}{|c|}{ Initiated proceedings } & \multicolumn{4}{|c|}{ Decisions } \\
\cline { 2 - 7 } & \multirow{2}{*}{ In general } & \multirow{2}{*}{$\begin{array}{c}\text { On the basis of } \\
\text { a police motion }\end{array}$} & & In general & \multicolumn{2}{|c|}{ In the following proceedings: } \\
\cline { 4 - 7 } & & 374736 & 442622 & 169631 & 2759 & 270232 \\
\hline 2007 & 440610 & & ordinary & accelerated & penal order \\
\hline 2008 & 444197 & 363106 & 426075 & 152128 & 1863 & 272084 \\
\hline 2009 & 485313 & 374681 & 461319 & 148648 & 1791 & 310880 \\
\hline 2010 & 524053 & 393553 & 493982 & 147301 & 1229 & 345452 \\
\hline 2011 & 490871 & 362767 & 492113 & 138849 & 1284 & 351980 \\
\hline 2012 & 461761 & 326040 & 447001 & 120361 & 1106 & 325534 \\
\hline 2013 & 497234 & 337658 & 472704 & 121759 & 1263 & 349682 \\
\hline 2014 & 590854 & 419477 & 553212 & 136897 & 1399 & 414916 \\
\hline 2015 & 576169 & 405443 & 567262 & 136838 & 900 & 429524 \\
\hline 2016 & 453668 & 377074 & 479538 & 122638 & 668 & 356232 \\
\hline $1^{\text {st }}$ half of & 205988 & 206235 & 165042 & 49655 & 349 & 156231 \\
\hline 2017 & & & & & & \\
\hline
\end{tabular}

Source: Elaborated by Karolina Orowiecka, Statistical Control Information Division of the Department of Strategy and European Funds of the Ministry of Justice, https://isws.ms.gov.pl/pl/bazastatystyczna/opracowania-wieloletnie/ [access: 24.10.2017]. 


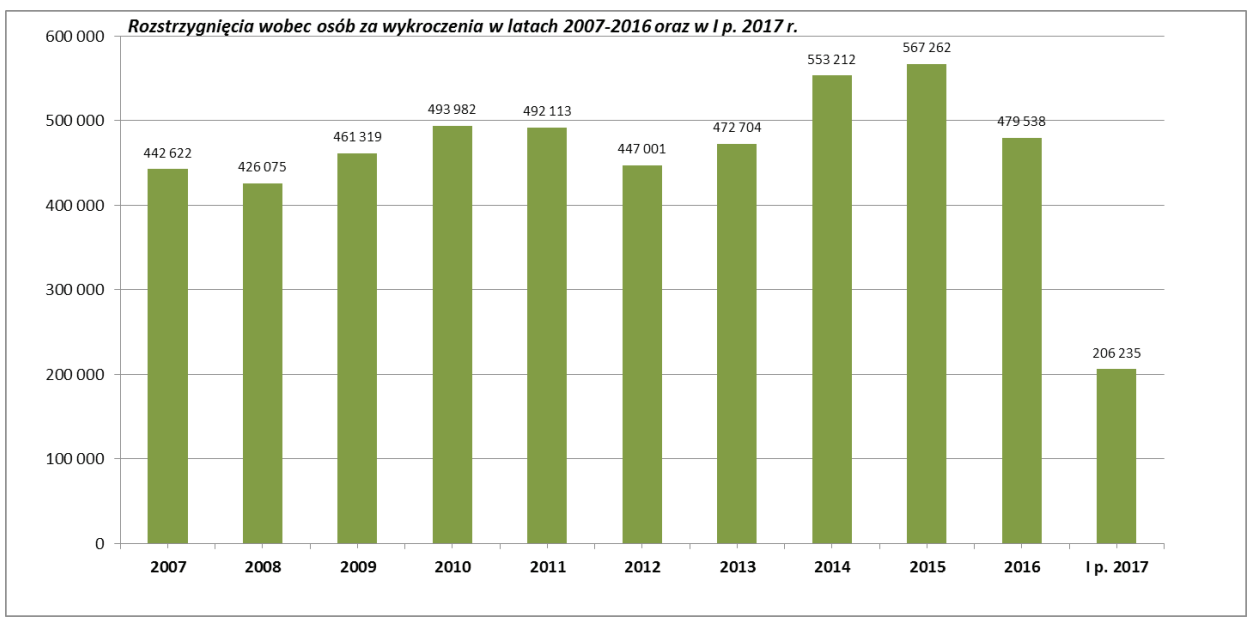

Figure 1 . The number of decisions on persons charged with petty offenses in the years 2007-2016 and in the first half of 2017

Source: Elaborated by Karolina Orowiecka, Statistical Control Information Division of the Department of Strategy and European Funds of the Ministry of Justice, https://isws.ms.gov.pl/pl/ baza-statystyczna/opracowania-wieloletnie/ [access: 24.10.2017].

Taking into account the character of the acts and the degree of their social harmfulness it should be considered whether de lege ferenda the petty offences which are characterised by a low level of social harmfulness should not be examined in general in accelerated proceedings as the only and obligatory mode.

Whereas these petty offences whose social harmfulness is greater, which is visible in the fact that they are punished with arrest or restriction of liberty, should be moved to the category of misdemeanors in the future and placed in the Criminal Code. Such a distinction would make it possible to introduce changes leading to the examination of minor cases, characterised by simple circumstances, by legal secretaries within the framework of the existing criminal chambers or in specially created chambers in the regional courts.

Such a solution would make it possible to unburden the judges and courts in criminal courts as far as the minor cases are concerned, which in many cases should not be directed to the court at all and whose legal circumstances make it possible to reach a quick decision. 


\section{BIBLIOGRAPHY}

Cieślak, W., Postępowanie przyspieszone, [in:] F. Prusak (red.), System prawa karnego procesowego. Tryby szczególne, t. XIV, Warszawa 2014.

Dąbkiewicz, K., Komentarz do art. 90 Kodeksu postępowania w sprawach o wykroczenia, legal status for 2014.09.01, LEX 2017.

Dmowski, S., [in:] S. Dmowski, S. Rudnicki, Komentarz do Kodeksu cywilnego. Księga pierwsza. Część ogólna, wyd. 10, Warszawa 2011.

Grzegorczyk, T., Kodeks postępowania w sprawach o wykroczenia. Komentarz, wyd. 5, Warszawa 2012.

Grzegorczyk, T., Komentarz do art. 92 Kodeksu postepowania w sprawach o wykroczenia, LEX 2012, vol. 2.

Grzegorczyk, T., Postępowania szczególne w sprawach o wykroczenia, „Prokuratura i Prawo” 2002, nr 1.

Kotowski, W., Kurzępa, B., Kodeks postępowania w sprawach o wykroczenia. Komentarz, wyd. 3, Warszawa 2016.

Lewiński, J., Komentarz do art. 91 Kodeksu postępowania w sprawach o wykroczenia, legal status for: 2011.04.01, http://wpia.lex.umcs.lublin.pl/lex/content,rpe?/reqld=1508757429389_17913 98723\&localNro part $=587483819 \&$ nro $=201336070$ [access: 23.10 .2017$]$.

Lewiński, J., Komentarz do Kodeksu postępowania w sprawach o wykroczenia, Warszawa 2009.

Paśkiewicz, J., [in:] M. Rogalski (red.), Kodeks postępowania w sprawach o wykroczenia. Komentarz, Warszawa 2009.

Rogalski, M., Komentarz do art. 92 Kodeksu postępowania w sprawach o wykroczenia, LEX 2009, vol. 1.

Strzebińczyk, J., [in:] E. Gniewek, P. Machnikowski (red.), Kodeks cywilny. Komentarz, wyd. 7, Warszawa 2016.

Waltoś, S., Hofmański, P., Proces karny. Zarys systemu, wyd. 13, Warszawa 2016.

Zgryzek, K., Skargi zastepujace akt oskarżenia w polskim procesie karnym, [in:] A. GereckaŻołyńska, P. Górecki, H. Paluszkiewicz, P. Wiliński (red.), Skargowy model procesu karnego. Ksiega ofiarowana Profesorowi Stanistawowi Stachowiakowi, Warszawa 2008.

III KK 96/11, KZS 2011, No. 9, position 37, LEX 2017 No. 795787.

Journal of Laws of 2001, No. 106, position 1149 as amended.

Journal of Laws of 2016, position 1749 as amended.

Statute from March 20, 2009 on the safety of mass events, Journal of Laws of 2015, position 2139 as amended.

Supreme Court's Verdict of 7 March 2012, K.K. 39/12, OSNK 2012, No. 6, position 67.

\section{SUMMARY}

The author discusses the issue of accelerated proceedings in petty offences cases. She stresses the fact that the examination of a case in the accelerated mode depends on the presence of special conditions of these proceedings and the free decision of the body entitled to initiate court proceedings by its motion for punishment. The paper contains the analysis of those solutions which, on the basis of Art. 57 of the Code of Proceedings in Petty Offences Cases get especially simplified within the framework of accelerated proceedings.

Keywords: accelerated proceedings; motion for punishment; break in trial; examining a case "without unnecessary delay"; motion for sentence motives 


\section{STRESZCZENIE}

Autorka porusza problematykę postępowania przyspieszonego w sprawach o wykroczenia. Wskazuje, że rozpoznanie sprawy w trybie przyspieszonym uzależnione jest od wystąpienia szczególnych przesłanek tego postępowania i swobodnej decyzji organu upoważnionego do uruchomienia wnioskiem o ukaranie postępowania przed sądem. W artykule zostały przeanalizowane te instytucje, które na podstawie art. 57 k.p.w. doznają szczególnych uproszczeń w ramach ukształtowania procesu przyspieszonego.

Słowa kluczowe: tryb przyspieszony; wniosek o ukaranie; przerwa w rozprawie; rozpoznanie sprawy „bez zbędnej zwłoki”; wniosek o uzasadnienie wyroku 
